\title{
MENINGKATKAN MOTIVASI BELAJAR DENGAN METODE TEAM QUIZ (SEBUAH METODE PEMBELAJARAN SEJARAH DI ERA MILENIAL)
}

\author{
M. Rasyid Ridha, Bustan, Nurhidayah \\ Email : rasyid ridha@unm.ac.id, bustan@unm.ac.id \\ Jurusan Sejarah UNM
}

\begin{abstract}
Abstrak
Tulisan ini mengungkap motivasi belajar siswa pada mata pelajaran sejarah dengan Metode Pembelajaran Team Quiz.Pembelajaran sejarah di sekolah seringkali dianggap pelajaran yang membosankan karena penuh dengan hapalan-hapalan angka tahun, nama, dan tempat kejadian. Padahal pada hakikatnya pembelajaran sejarah mampu mengembangkan kompetensi berpikir secara kronologis dan memiliki pengetahuan tentang masa lampau yang dapat digunakan untuk memahami dan menjelaskan proses perkembangan dan perubahan masyarakat serta keragaman sosial budaya dalam rangka menemukan dan menumbuhkan jati diri bangsa di tengah-tengah kehidupan masyarakat dunia. Pembelajaran sejarah juga bertujuan agar siswa menyadari adanya keragaman pengalaman hidup pada masing-masing masyarakat dan adanya cara pandang yang berbeda terhadap masa lampau untuk memahami masa kini dan membangun pengetahuan serta pemahaman untuk menghadapi masa yang akan datang.Jenis penelitian ini adalah Penelitian Tindakan Kelas yang didesain dalam dua siklus yaitu siklus I dan siklus II, dengan alur penelitian terdiri dari perencanaan, pelaksanaan, observasi atau pengamatan dan refleksi.Data yang digunakan dalam penelitian diperoleh melalui observasi dan angket kemudian dianalisis secara kualitatif dan kuantitatif.
\end{abstract}

Kata Kunci: Meningkatkan, Motivasi Belajar, metode team quuiz, era milenial

\section{Pendahuluan}

Pendidikan merupakan bagian yang tidak terpisahkan dengan pembangunan. Pembangunan yang dimaksud diarahkan dengan tujuan untuk mengembangkan Sumber Daya Manusia (SDM) yang berkualitas. ${ }^{1}$ Dalam meningkatkan kualitas pembelajaran di dalam lembaga pendidikan formal misalnya sekolah, maka berbagai komponen pembelajaran, seperti; sarana dan prasarana, kualitas pendidik dan ketersediaan sumber belajar sangat diperlukan. dimana hal tersebut ditegaskan dalam pasal 45 ayat (1) undang-undang Nomor 20 tahun 2003 tentang sistem pendidikan nasional bahwa:

"Setiap satuan pendidikan formal dan non formal menyediakan sarana dan prasarana yang memenuhi keperluan pendidikan sesuai dengan pertumbuhan dan perkembangan

${ }^{1}$ Oemar Hamalik, Kurikulum dan Pembelajaran, (Jakarta : PT Bumi Aksara, 2003), hlm. 1.

363 | Seminar Nasional Sejarah ke 4 Jurusan Pendidikan Sejarah Universitas Negeri Padang 
potensi peserta didik, kecerdasan intelektual, sosial, emosional dan kejiwaan peserta didik."

Sejalan dengan pelaksanaan Undang-Undang Nomor 20 tahun 2003 tentang Sistem Pendidikan Nasional, bahwa Pendidikan adalah usaha sadar dan terencana untuk mewujudkan suasana belajar dan proses pembelajaran agar peserta didik secara aktif mengembangkan potensi dirinya untuk memiliki kekuatan spiritual keagamaan, pengendalian diri, kepribadian, kecerdasan, akhlak mulia, serta keterampilan yang diperlukan dirinya, masyarakat, bangsa dan negara. Hal ini adalah tugas dan sekaligus tantangan untuk semua unsur pelaksana pendidikan khususnya guru untuk senantiasa mengembangkan diri dalam mencari cara atau metode penyampaian bahan ajar yang dapat melibatkan siswa secara aktif dan interaktif, sehingga tujuan dari pembelajaran yang sudah ditetapkan dan dijabarkan dalam rencana pelaksanaaan pembelajaran dapat tercapai dengan baik.

Untuk memahami efektivitas pembelajaran pada suatu lembaga pendidikan formal perlu adanya kajian atau penelitian.Olehnya itu dilakukan Observasi awal disalah satu sekolah di Sulawesi Selatan yakni, SMA 11 Makassar. Dalam observasi tersebut ditemukan fakta,bahwa dalam proses pembelajaran sejarah siswa kurang aktif karena adanya kecenderunganpembelajaran berpusat pada guru dengan metode ceramah sedangkan siswa bersifat pasif, mendengarkan dan mencatat saja sehingga interaksi guru dengan siswa kurang.

Proses pembelajaran yang kebanyakan masih mengunakan paradigma yang lama dimana guru memberikan pengetahuan kepada siswa secara pasif. Siswa cenderung tidak tertarik dengan pelajaran Sejarah karena selama ini pelajaran Sejarah dianggap sebagai pelajaran yang hanya mementingkan hafalan semata, kurang menekankan aspek penalaran sehingga menyebabkan rendahnya motivasi belajar Sejarah siswa di sekolah.

Masalah utama dalam pembelajaran Sejarah di sekolah ialah penggunaan metode atau model pembelajaran dalam menyampaikan materi pelajaran secara tepat, yang memenuhi muatan tatanan nilai, agar dapat dipahami oleh siswa serta mengimplementasikan hakekat pendidikan nilai dalam kehidupan sehari-hari belum memenuhi harapan seperti yang diinginkan. Selain itu pemanfaatan media pembelajaran yang kurang, sehingga siswa kurang termotivasi ketika pembelajaran sedang berlangsung. Disamping masih menggunakan model pembelajaran yang monoton, aktivitas guru lebih dominan daripada siswa, akibatnya guru seringkali mengabaikan 
proses pembinaan tatanan nilai, sikap, dan tindakan, sehingga mata pelajaran Sejarah lebih cenderung menjadi mata pelajaran yang jenuh dan membosankan.

Berdasarkan kondisi tersebut, ditemukan masalah pembelajaran yaitu siswa kurang termotivasi saat pembelajaran Sejarah karena model pembelajaran yang dianggap kaku dan membosankan, sehingga perlu adanya pembelajaran yang bervariasi dan media pembelajaran yang disajikan dibuat semenarik mungkin.Hal inilah yang melatarbelakangi penulis untuk melakukan kajian dengan menggunakan model pembelajaran aktif Team Quiz dalam rangka meningkatkan motivasi belajar siswa di sekolah.

\section{Kajian Teoritis}

1. Belajar

Belajar bukan lagi istilah yang asing untuk didengar namun kita perlu mengkaji apa makna dari belajar. Sebagaimana dituturkan oleh Sardiman "belajar merupakan perubahan tingkah laku atau penampilan, dengan serangkaian kegiatan misalnyadengan membaca, mengamati, mendengarkan, maupun dengan meniru"2 . Dan menurut Hamalik "belajar adalah suatu proses perubahan tingkah laku individu dengan melalui interaksi dengan lingkungannya untuk mendapatkan suatu pengetahuan baru". 3

Dengan adanya pengertian diatas, disimpulkan bahwa pengertian belajar adalah suatu proses terjadinya perubahan tingkah laku siswa yang dapat dibandingkan dengan melihat kondisi siswa sebelum dan sesudah belajar. Tingkah laku merupakan suatu bagian dari tujuan yang mengarah pada hasil yang diharapkan dalam proses belajar. Adapun tujaun belajar yaitu untuk mendapatkan pengetahuan, pemahaman konsep dan keterampilan serta pembentukan sikap.

\section{Pembelajaran}

Pembelajaran adalah serangkaian aktivitas yang sengaja diciptakan dan dilaksanakan dengan maksud untuk membelajarkan siswa dalam memudahkan terjadinya proses belajar. Menurut Walter Dick pembelajaran sebagai rangkaian peristiwa atau kegiatan yang

\footnotetext{
${ }^{2}$ Sardiman,Interaksi dan motivasi belajar mengajar.(Jakarta:Rajawali pres,2010), hlm. 22.

${ }^{3} \mathrm{Op}$. Cit, hlm. 37.
}

365 | Seminar Nasional Sejarah ke 4 Jurusan Pendidikan Sejarah Universitas Negeri Padang 
disampaikan secara terstruktur dan terencana dengan menggunakan sebuah atau beberapa jenis media. ${ }^{4}$

Pembelajaran merupakan suatu kegiatan yang dilakukan secara sengaja yang dirancang untuk menciptakan terjadinya aktivitas belajar antara pendidik dengan peserta didik. Pembelajaran juga merupakan suatu proses untuk membantumember pelajaran kepada siswa dalam menghadapi kehidupan sehari-harinya agar bisa menjadi masyarakat yang baik.

3. Motivasi Belajar

Motivasi sangat erat kaitannya dengan kegiatan belajar mengajar sebab motivasi dibutuhkan dalam rangka menumbuhkan minat belajar peserta didik. Sehingga kita perlu mengetahui apa arti dari motivasi. Istilah motivasi berasal dari kata "motif" yang artinya sebagai daya upaya yang mendorong seseorang untuk melakukan sesuatu. Motif tidak dapat diamati secara langsung tetapi dapat dilihat dari tingkah laku siswa.Motif adalah daya penggerak dalam diri seseorang untuk melakukan aktivitas tertentu demi mencapai suatu tujuan ${ }^{5}$.Adapun pengertian motivasi menurut Hamalik adalah "suatu perubahan energi dalam diri seseorang yang ditandai oleh timbulnya perasaan dan reaksi untuk mencapai tujuan" .sedangakan menurut Hakim motivasi adalah "sesuatu yang mendorong individu untuk berperilaku yang langsung menyebabkan munculnya perilaku". ${ }^{7}$ Serta pengertian motivasi menurut Sanjaya adalah aspek yang sangat penting untuk membelajaran siswa. ${ }^{8}$

Motivasi belajar merupakan suatu proses yang sangat penting untuk membelajarkan siswa dengan memberikan dorongan yang memungkinkan siswa untuk bertindak atau melakukan sesuatu agar bisa terjadi perubahan energi dalam diri seseorang yang dapat ditandai dengan timbulnya perasaan dan reaksi untuk mencapai tujuan. Adapun fungsi dari motivasi adalah :

(1) Mendorong timbulnya tingkah laku atau perbuatan. Tanpa motivasi tidak akan timbul suatu perbuatan misalnya belajar. (2) Motivasi berfungsi sebagai pengarah, artinya mengarahkan perbuatan untuk mencapai tujuan yang diinginkan. (3) Motivasi

\footnotetext{
${ }^{4}$ Benny A. Pribadi, Model Desain Sistem Pembelajaran, (Jakarta: Dian Rakyat, 2009), hlm 11

${ }^{5}$ Op.Cit, hlm. 73.

${ }^{6}$ Oemar Hamalik,Kurikulum dan Pembelajaran, (Jakarta : Bumi Aksara, 2003), hlm.121.

${ }^{7}$ Lukmanul Hakiim, Perencanaan Pembelajaran, (Bandung : CV Wacana Prima, 2011), hlm. 35.

${ }^{8}$ Wina Sanjaya, Kurikulum dan Pembelajaran,(Jakarta: Kencana, 2008), hlm. 228.
} 366 | Seminar Nasional Sejarah ke 4 Jurusan Pendidikan Sejarah Universitas Negeri Padang 
juga berfungsi sebagai, artinya menggerakkan tingkah laku seseorang. Besar kecilnya motivasi akan menentukan cepat atau lambatnya suatu pekerjaan. ${ }^{9}$

Dengan adanya fungsi motivasi sebagai pendorong usaha dalam mengarahkan dan menggerakkan tingkah laku siswa untuk mencapai suatu prestasi yang ingin dicapai oleh siswa itu sendiri. Karena tanpa adanya suatu motivasi dalam diri siswa maka siswa tidak akan memiliki kemauan untuk belajar.

Untuk membangkitkan motivasi siswa maka guru harus dapat menunjukan pengalaman dan materi belajar bagi kehidupan siswa, maka dari itu siswa akan belajar bukan hanya sekedar untuk memperoleh nilai atau pujian tetapi akan didorong oleh keinginan untuk memenuhi kebutuhannya. Dalam meningkatkan motivasi belajar siswa maka para pendidik harus menggunakan model pembelajaran yang dapat mengaktifkan siswa didalam kelas.

\section{Pembelajaran Team Quiz}

Model pembelajaran menurut Joyce dalam Trianto adalah suatu perencanaan atau suatu pola yang digunakan sebagai pedoman dalam merencanakan pembelajaran di kelas yang tujuannya untuk mengarahkan kita dalam mendesain pembelajaran untuk membantu peserta didik sedemikian rupa sehingga tujuan pembelajaran tercapai. ${ }^{10}$ Adapun pengertian pembelajaran menurut Rusman adalah suatu rencana atau pola yang dapat digunakan untuk membentuk kurikulum (rencana pembelajaran jangka panjang), merancang bahan-bahan pembelajaran dan membimbing pembelajaran di kelas. ${ }^{11}$

Model pembelajaran yang digunakan untuk meningkatkan motivasi belajar siswa yaitu model pembelajaran Team Quiz yang dikemukakan oleh Dalvi merupakan salah satu tipe pembelajaran yang mampu meningkatkan keaktifan siswa dalam proses belajar yang berpusat pada siswa itu sendiri. Dimana pada model pembelajaran ini, siswa berperan secara aktif dalam proses pembelajaran dan kemudian dibagi ke dalam beberapa kelompok. Langkah-langkah model pembelajaran Team Quizyaitu :

a. Memilih topik yang dapat disampaikan kedalam beberapa bagian.

b. $\quad$ Membangi siswa kedalam beberapa kelompok, misalnya kelompok A,B, dan C, D

\footnotetext{
${ }^{9}$ Ibid, hlm.108.

${ }^{10}$ Trianto, Mendesain Model Pembelajaran Inovatif-Progresif,(Jakarta: Kencana, 2010), hlm. 22.

${ }^{11}$ Rusman, Model-Model Pembelajaran Mengembangkan Propesional Guru, (Jakarta: Raja Wali Pers,
} 2011), hlm. 144-145.

367 | Seminar Nasional Sejarah ke 4 Jurusan Pendidikan Sejarah Universitas Negeri Padang 
c. Menyampaikan kepada siswa tentang format pelajaran kemudian menyampaikan materi. Batas maksimal penyampaian materi selama 10 menit.

d. Setelah menyampaikan meteri, kemudian kelompok pertama (A) menyiapkan pertanyaan yang berkaitan dengan materi yang sudah disampaikan. Kemudian kelompok B dan C menggunakan waktu tersebut untuk melihat catatan mereka.

e. Kemudian mintala kelompok A untuk memberi pertanyaan kepada kelompok B. Apabila kelompok B tidak bisa menjawab maka lemparkan pertanyaan tersebut kepada kelompok C.

f. Selanjutnya kelompok A memberi pertanyaan kepada kelompok C, jika kelompok $\mathrm{C}$ tidak bisa menjawab maka lemparkan pertanyaan tersebut kepada kelompok B untuk menjawab.

g. Jika Tanya jawab selesai, maka lanjutkan pelajaran kedua kemudian tunjuk kelompok B untuk menjadi kelompok penanya. Kemudian lanjutkan seperti pada proses kelompok A.

h. Setelah kelompok B selesai dengan pertanyaannya, maka lanjutkan lagi penyampain materi pelajaran ketiga kemudian tunjuk kelompok $\mathrm{C}$ sebagai kelompok penanya. Kemudian lakukan kembali seperti pada proses kelompok A dan kelompok B yaitu memberikan pertanyaan kepada kelompok lawannya seperti pada segmen sebelumnya.

i. $\quad$ Setelah kelompok $\mathrm{C}$ menyelesaikan pertanyaannya, maka akhiri pelajaran dengan menyimpulkan tanya jawab kemudian jelaskan kepada siswa tentang pemahaman yang masih keliru jika ada. ${ }^{12}$

\section{Metode Penelitian}

\section{Jenis Penelitian}

Jenis penelitian ini adalah penelitian tindakan kelas (classroom action research). Menurut Rapoport mendefinisikan penelitian tindakan kelas adalah penelitian untuk membantu seseorang dalam mengatasi secara praktis persoalan yang dihadapi dalam situasi 2009), hlm. 114.

12 Agus Suprijono, Cooperative Learning Teori dan Aplikasi Paikem, (Yogyakarta: Pustaka Pelajar, 368 | Seminar Nasional Sejarah ke 4 Jurusan Pendidikan Sejarah Universitas Negeri Padang 
darurat dan membantu pencapaian tujuan ilmu sosial dengan kerja sama dalam kerangka etika yang disepakati bersama. ${ }^{13}$ Penelitian TindakanKelas adalah suatu pendekatan untuk meningkatkan pendidikan dengan melakukan perubahan kearah perbaikan terhadap hasil pendidikan dan pembelajaran dengan menggunakan empat tahap yaitu perencanaan, pelaksanaan, observasi dan refleksi . Karena pada intinya penelitian tindakan kelas merupakan suatu penelitian yang akar permasalahannya muncul di kelas, dan dirasakan langsung oleh guru yang bersangkutan sehingga sulit dibenarkan jika ada anggapan bahwa permaslahan dalam penelitian tindakan kelas diperoleh dari persepsi seorang peneliti.

\section{Desain Penelitian}

Prosedur Penelitian Tindakan Kelas (PTK) ini direncanakan dalam dua siklus, yaitu siklus I dan siklus II. Gambaran umum yang dilakukan pada setiap siklus adalah: Perencanaan, Pelaksanaan, Observasi, dan Refleksi yang digambarkan sebagai berikut:

\section{Gambar 1: Skema Penelitian Tindakan Kelas}

A. Hasil Peneliti: 1. Siklus I Pengar
masih ada sis
menjawab per
dengan teman-
Pelaksi kelas masih terdapat kendala-kendala seperti, rebut, mengganggu temannya yang ada dikelompok lain dan melakukan kegiatan diluar pembelajaran. Pada akhir pembelajaran materi disimpulkan dan menasehati siswa dan hanya sedikit siswa yang mendengarkan karena siswa begitu ribut dan terburu-buru ingin keluar dari kelas untuk kekantin pada saat proses pembelajaran berakhir.

\footnotetext{
${ }^{13}$ Kunandar, Langkah Mudah Penelitian Tindakan Kelas Sebagai Pengembangan Profesi Guru, (Jakarta: PT Rajawali Pers, 2010), hlm. 46. 
Selain itu, data kuantitatif berupa angket motivasi belajar yang dibagikan oleh siswa pada setiap akhir siklus.Angket tersebut berupa pertanyaan-pertanyaan yang berjumlah 20 item yang tujuannya untuk mengetahui peningkatan peningkatan motivasi siswa. Berdasarkan hasil angket motivasi belajar, maka distribusi frekuensi dan persentase motivasi belajar siswa sebagaimana pada tabel berikut;

Tabel 1: Distribusi frekuensi dan Persentase skor motivasi belajar siswa siklus I

\begin{tabular}{ccccc}
\hline No & $\begin{array}{c}\text { Rentang Skor } \\
(\%)\end{array}$ & Kategori & Frekuensi & $\begin{array}{c}\text { Persentase } \\
(\%)\end{array}$ \\
\hline 1 & $86-100$ & Sangat Tinggi & 1 & 4,16 \\
2 & $76-85$ & Tinggi & 12 & 49,92 \\
3 & $60-75$ & Sedang & 8 & 33,28 \\
4 & $55-59$ & Rendah & 0 & 0 \\
5 & $\leq 54$ & Sangat Rendah & 3 & 12,48 \\
\hline \multicolumn{5}{c}{ Jumlah } \\
\hline \multicolumn{5}{c}{ Skor rata-rata } \\
\hline
\end{tabular}

Dari tabel di atas, dapat digambarkan bahwa dari 24 orang siswa yang telah mengisi angket motivasi belajar siswa siklus I, terdapat $3 \%$ siswa yang motivasi belajarnya berada pada kategori sangat rendah, rendah $0 \%$, sedang $8 \%$, tinggi $12 \%$, dan sangat tinggi $1 \%$ dengan skor rata-rata $67,37 \%$. Berdasarkan hasil angket motivasi belajar siswa pada siklus I dianggap belum tuntas/optimal karena persentase rata-ratamotivasi belajara siswa hanya 67,37 \% atau berada pada kategori sedang. Sehingga peneliti perlu melanjutkan ke siklus berikutnya karena belum mencapai indikator keberhasilan yang telah di tetapkan.

\section{Hasil Penelitian Siklus II}

Adapun hal-hal yang akan dilakukan pada siklus II yaitu mengulang kembali langkah-langkah pada saat pembelajaran sejarah berlangsung dengan menerapkan kembali model pembelajaran Team Quiz dengan materi yang berbeda pada siklus I yaitu dengan materi kerajaan-kerajaan Islam di Indonesia, menyusun kembali materi yang akan di kuiskan pada tindakan siklus II yang dilakukan untuk memperbaiki hasil dari siklus I.

Berdasarkan pada kegiatan Siklus II ini, mulai dari perencanaan, pelaksanaan tindakan, observasi semua sudah mengalami kemajuan kearah positif.Sebagian siswa sudah begitu aktif dalam melaksanaakan tugas-tugas pembelajaran. Pada Siklus II guru dapat 
memperbaiki kekurangan yang terdapat di Siklus I, siswa kemudian dapat mengikuti pembelajaran dengan baik sesuia dengan model pembelajaran Team Quiz yang diterapkan oleh guru (peneliti). Dari refleksi ini peneliti tidak melakukan perencanaan untuk Siklus selanjutnya karena peneliti hanya melakukan sebanyak dua Siklus, dan motivasi belajar siswa sudah bersemangat untuk belajar dan memperhatikan guru pada saat menjelaskan.

Maka secara umun dapat dikatakan bahwa seluruh kegiatan pada Siklus II ini mengalami peningkatan dibanding dari Siklus I. Karena pada Siklus II dapat terlihat dari keseriusan siswa memperhatikan pelajaran yang diberikan oleh guru dan keaktifan siswa untuk bertanyaan kepada lawan kelompoknya dan siswa sudah berani tampil didepan temannya untuk menjawab pertanyaan dari teman-temannya sendiri.

Data kuantitatif berupa angket motivasi belajar yang dibagikan oleh siswa pada setiap akhir siklus.Angket tersebut berupa pertanyaan-pertanyaan yang berjumlah 20 item yang tujuannya untuk mengetahui peningkatan peningkatan motivasi siswa. Berdasarkan hasil angket motivasi belajar siswa, skor dikelompokkan berdasarkan skala likert, maka distribusi frekuensi dan persentase motivasi belajar siswa sebagaimana pada tabel di halam selanjutnya:

\section{Tabel 2: Distribusi Frekuensi dan Persentase Skor Motivasi Belajar Siswa Siklus II}

\begin{tabular}{ccccc}
\hline No & $\begin{array}{c}\text { Rentang Skor } \\
(\%)\end{array}$ & Kategori & Frekuensi & Persentase \\
\hline 1 & $86-100$ & Sangat Tinggi & 1 & 4,16 \\
2 & $75-85$ & Tinggi & 16 & 66,56 \\
3 & $60-74$ & Sedang & 7 & 29,12 \\
4 & $55-59$ & Rendah & 0 & 0 \\
5 & $\leq 54$ & Sangat Rendah & 0 & 0 \\
\hline \multicolumn{5}{c}{ Jumlah } \\
\hline \multicolumn{5}{c}{ Skor rata-rata } \\
\hline
\end{tabular}

Dari tabel2 diatas tersebut dapat digambarkan bahwa dari 24 orang siswa yang telah mengisi angket motivasi belajar siswa siklus II, terdapat $0 \%$ siswa yang motivasi belajarnya berada pada kategori sangat rendah, rendah $0 \%$, sedang $7 \%$, tinggi $16 \%$, dan sangat tinggi $1 \%$ dengan skor rata-rata $78,12 \%$. Berdasarkan hasil angket motivasi belajar siswa pada siklus II dapat disimpulkan bahwa terjadi peningkatan persentase motivasi belajar siswa sebesar $10,75 \%$.

371 | Seminar Nasional Sejarah ke 4 Jurusan Pendidikan Sejarah Universitas Negeri Padang 


\section{Pembahasan}

Team Quiz merupakan model pembelajaran aktif, yang mana dalam Team Quiz ini siswa dibagi menjadi beberapa kelompok. Setiap siswa dalam tim bertanggung jawab untuk menyiapkan kuis jawaban singkat, dan kelompok yang lain menggunakan waktunya untuk memeriksa catatan. Dalam Team Quiz ini, diawali dengan guru menerangkan materi secara klasikal, lalu siswa dibagi kedalam beberapa kelompok.Semua anggota kelompok bersama-sama mempelajari materi tersebut, saling memberi arahan, saling memberikan pertanyaan dan jawaban untuk memahami mata pelajaran tersebut.Setelah selesai materi maka diadakan suatu pertandingan akademis.

Dengan adanya pertandingan akademis ini maka terciptalah kompetisi antar kelompok, para siswa akan senantiasa berusaha belajar dengan motivasi yang tinggi agar dapat memperoleh nilai yang tinggi dalam pertandingan. Salah satu upaya untuk membangkitkan siswa belajar aktif pada mata pelajaran Sejarah yaitu dengan penggunaan model pembelajaran Team Quiz.

Pada pelaksanaan siklus II mengalami peningkatan dibandingkan dari siklus I karena dari 24 orang siswa sudah mengisi semua angket motivasi belajar sejarah siswa, dan guru juga sudah bisa mengorganisis siswa kedalam kelompok belajar sejarah sehingga kondisi siswa pada siklus II dapat terkontrol dengan baik pada saat guru mengarahkan siswa melaksanakan model pembelajaran Team Quiz siswa sudah aktif dikelas dan berani tampil didepan teman-temanya dan tidak malu-malu lagi menjawab pertanyaan dari lawan kelompoknya.

Tabel 3: Perbandingan Distribusi Frekuensi Motivasi Belajar Siswa

\begin{tabular}{cccccc}
\hline Rentang & \multicolumn{2}{c}{ Siklus I } & \multicolumn{2}{c}{ Siklus II } & \multirow{2}{*}{ Kategori } \\
\cline { 2 - 5 } Skor $(\%)$ & Frekuensi & Persentase (\%) & Frekuensi & Persentase (\%) & \\
\hline $86-100$ & 1 & 4,16 & 1 & 4,16 & Sangat tinggi \\
$76-85$ & 12 & 49,92 & 16 & 66,56 & Rendah \\
$60-75$ & 8 & 33,28 & 7 & 29,12 & Sedang \\
$55-59$ & 0 & 0 & 0 & 0 & Tinggi \\
$\leq 54$ & 3 & 12,48 & 0 & 0 & Kurang \\
\hline Jumlah & 24 & $100 \%$ & 24 & $100 \%$ & \\
\hline \multicolumn{2}{r}{ Rata-rata } & 67,37 & Rata-rata & 78,12 & \\
\hline
\end{tabular}

Dari tabel diatas dapat menunjukkan perbandingan hasilangketmotivasi belajar siswa dan meningkatnya rata-rata nilai dari siklus I dan siklus II yakni 67,37 menjadi 78,12peningkat hasil 
angket motivasi siswa dari siklus I ke siklus II sebanyak10,75\%.Dengan adanya tabel diatas sehingga dapat mengetahui peningkatan motivasi belajar siswa dengan diterapkannya model pembelajaran Team Quiz.

\section{Simpulan}

Adanya permasalahan yang dihadapi oleh siswa pada saat proses pembelajaran Sejarah berlangsung membuat siswa tidak aktif di dalam kelas sehingga peneliti perlu menerapkan model Team Quiz merupakan model pembelajaran aktif, semua anggota kelompok bersama-sama mempelajari materi tersebut, saling memberi arahan, saling memberikan pertanyaan dan jawaban untuk memahami mata pelajaran tersebut. Setelah selesai materi maka diadakan suatu pertandingan akademis.diterapkannya model pembelajaran Team Quiz di kelas motivasi belajar siswa meningkat. Hal ini dapat dilihat dari hasil angket motivasi belajar siswa yang dilaksanakan setiap akhir siklus. Pada siklus I persentase rata-rata motivasi belajar siswa sebesar 67,37\% berada pada kategori sedang. Pada siklus II persentase rata-rata motivasi belajar siswa sebesar $78,12 \%$ atau berada pada kategori tinggi dengan persentase peningkatan sebesar 10,25\%.

\section{DAFTAR PUSTAKA}

A Pribadi, Benny.2009. Model Desain Sistem Pembelajaran. Jakarta: Dian Rakyat. Hamalik, Oemar. 2003. Kurikulum dan Pembelajaran. Jakarta : PT. Bumi aksara. Hakim, Lukman. 2011. Perencanaan Pembelajaran. Bandung : CV Wacana Prima Kunandar.2010. Langkah Muda Penelitian Tindakan Kelas sebagai Pengembangan Profesi Guru.Jakarta : Rajawali Press

Suprijono, Agus. 2009. Cooverative Learning, Teori dan Aplikasi. Yogyakarta : Pustaka Pelajar Sardiman. 2010. Interaksi dan Motivasi Belajar Mengajar. Jakarta:Rajawali Press 